IZA DP No. 7063

Competition and Educational Productivity: Incentives Writ Large

W. Bentley MacLeod

Miguel Urquiola

December 2012 


\title{
Competition and Educational Productivity: Incentives Writ Large
}

\author{
W. Bentley MacLeod \\ Columbia University, \\ NBER and IZA \\ Miguel Urquiola \\ Columbia University \\ and NBER
}

Discussion Paper No. 7063

December 2012

\author{
IZA \\ P.O. Box 7240 \\ 53072 Bonn \\ Germany \\ Phone: +49-228-3894-0 \\ Fax: +49-228-3894-180 \\ E-mail: iza@iza.org
}

\begin{abstract}
Any opinions expressed here are those of the author(s) and not those of IZA. Research published in this series may include views on policy, but the institute itself takes no institutional policy positions. The IZA research network is committed to the IZA Guiding Principles of Research Integrity.

The Institute for the Study of Labor (IZA) in Bonn is a local and virtual international research center and a place of communication between science, politics and business. IZA is an independent nonprofit organization supported by Deutsche Post Foundation. The center is associated with the University of Bonn and offers a stimulating research environment through its international network, workshops and conferences, data service, project support, research visits and doctoral program. IZA engages in (i) original and internationally competitive research in all fields of labor economics, (ii) development of policy concepts, and (iii) dissemination of research results and concepts to the interested public.
\end{abstract}

IZA Discussion Papers often represent preliminary work and are circulated to encourage discussion. Citation of such a paper should account for its provisional character. A revised version may be available directly from the author. 


\section{ABSTRACT}

\section{Competition and Educational Productivity: Incentives Writ Large}

Friedman (1962) suggested that in general, unfettered markets ensure the efficient provision of goods and services. Applying this logic to Education, he recommended that students be provided with vouchers and allowed to purchase schooling services in a free market ((Friedman $(1955,1962))$. Hoxby (2002) refines this argument and suggests that more choice will lead to higher school productivity. We discuss the evidence in this area, concluding that the impact of competition has proven to be more mixed and modest than expected. We suggest that this in fact should not be surprising, since economic theory on incentives and incomplete contracts (beginning with many contributions also from the 1950s) leads to a more nuanced expectation. Specifically, an examination of the incentives faced by schools, parents, and students leads to predictions that are broadly consistent with the evidence, and suggests that there is no a priori reason to believe that school choice will dramatically improve test scores. We describe a simple model that illustrates this point and further implies that elements of market design might be necessary to ensure that competition enhances educational performance.

JEL Classification: D2, D8, J3, 12

Keywords: $\quad$ education, markets, information

Corresponding author:

W. Bentley MacLeod

Department of Economics

420 West 118th, Mail Code 3308

New York, NY 10027-7296

USA

E-mail: bentley.macleod@columbia.edu

\footnotetext{
* Forthcoming, Chapter 7 in Education Policy in Developing Countries, Paul Glewwe, Editor, University of Chicago Press. We thank Lorne Carmichael, Sebastian Galiani, Paul Glewwe, Patrick McEwan, and workshop participants for helpful comments. For excellent research assistance we thank Wilfredo Lim and Evan Riehl. We are grateful for funding from the International Growth Center and the Russell Sage Foundation. All opinions and remaining errors are our own.
} 
1. Under-recognition of the power of what psychologists call "reinforcement" and economists call "incentives."-Well I think I've been in the top 5 percent of my age cohort all my life in understanding the power of incentives, and all my life I've underestimated it. And never a year passes but I get some surprise that pushes my limit a little farther.

- Charlie Munger's first cause of human misjudgment, Speech at Harvard Law School.

\section{INTRODUCTION}

At the core of modern Economics is an effort to understand how institutions shape incentives, and how this affects the performance of the economy. A central institution is the market mechanism, under which firms are free to enter with new products, and consumers are free to decide whether to purchase them or not. One of the most influential proponents of this institution was Milton Friedman, who argued in his classic book, Capitalism and Freedom (Friedman (1962)), that all areas of economic activity can be enhanced with more reliance upon free markets and less reliance upon government provision of goods and services.

In the case of education, Friedman $(1955,1962)$ argued that allowing a greater role for private schools, and more freedom of choice for parents, would improve outcomes. He acknowledged that doing so might have distributional implications, but pointed out that these could be addressed via the distribution of vouchers, ensuring that each student received at least a minimum amount of education. This view has been influential; for example, it figures prominently in the World Bank's (2004) World Development Report on improving public service delivery.

In a review of the literature, Hoxby (2002) describes how these ideas have been explored theoretically and empirically. Hoxby points out that partially due to its origins in Public Finance, research on school choice has emphasized questions related to distribution rather than to productivity: "School choice research has concentrated on allocation questions, which include: Who exercises school choice? Who chooses which school? How does choice change the allocation of resources? How does reallocation of students change peer effects?"

Hoxby argues for research to place greater emphasis on school productivity. In her definition, "a school that is more productive is one that produces higher achievement in its pupils for each dollar it spends." This definition is precise and useful, and since it concerns testing

\footnotetext{
${ }^{1}$ It is indeed the case that seminal theoretical papers (e.g., Arnott and Rowse (1987) and Epple and Romano (1998)) focus on peer effects and hence on how competition would affect the distribution of students and educational outcomes. Later versions of such models do feature reduced-form productivity effects from competition, see for example Epple and Romano (2008).
} 
achievement, we will call it test productivity. Hoxby argues that competition would have large effects on school productivity, rendering distribution-related concerns less salient (i.e., it would be "a rising tide that lifted all boats").

Ascertaining the effects of competition on productivity is particularly relevant given findings that many school systems have experienced a test productivity "collapse." For example, Hanushek (1996) describes an apparent test productivity decline in American schools, and Pritchett (2003) suggests that this development is common among OECD countries. Data restrictions make it harder to make analogous statements about developing countries, but the prima facie evidence is consistent with many countries also having experienced rising real expenditures in education, with at best small test score gains to show for it.

Given this background, this paper carries out three tasks:

(1) We review the empirical evidence on the effects of competition on test productivity. We do not attempt to provide an exhaustive accounting of the literature; rather, we begin with a discussion of recent reviews of the voluminous U.S. literature. We then discuss the evidence from developing countries, focusing upon Chile, Colombia, India, and Pakistan - cases where there has been important work that extends the insights from the U.S. literature. We conclude that the impact of competition upon test productivity has proven to be more mixed and modest than would be expected given the evident success of privatization in other industries. ${ }^{2}$

(2) We then take a step back and ask if - given the advances in the economics of industrial organization, contract theory, and asymmetric information since the $1950 \mathrm{~s}$ - this is so surprising. We argue that in fact the literature in these areas suggests that there is no a priori reason to believe that school choice will lead to much higher test productivity. The fundamental reason is that in a rational choice framework parents and teachers care about the impact of education upon future wages, and not about test scores per se. In MacLeod and Urquiola (2012) we show that a school's reputation is a function not only of its value added, but also of its students' ability and effort. It is not always possible for the market to disentangle these three components, with the consequence that free competition may even lead to lower overall performance.

(3) We conclude with a discussion of the implications of these observations for the design of education markets. In particular, effective school competition requires design ingredients that unfettered markets are unlikely to produce. For example, all else equal competition will work better if policy restricts the right of schools to select their student body (consistent with the requirement that charter schools use a lottery

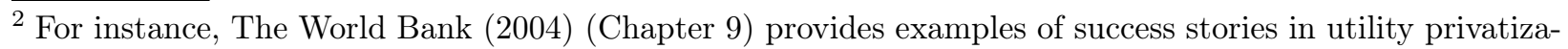
tion.
} 
system for admissions under No Child Left Behind legislation in the U.S.). This can be combined with high quality national exams, as suggested by Bishop (1997).

\section{THE EMPIRICAL EVIDENCE}

The educational literature contains an expectation that competition will substantially raise school test productivity. The reviews of the literature, such as McEwan (2004) and Barrow and Rouse (2009), emphasize that the benefits of allowing private schools to enter the market, and distributing vouchers to students, would originate from three effects:

(1) A private school productivity advantage. If private schools are more productive than public schools, then simply shifting children into the private sector will increase learning.

(2) A productivity-enhancing incentive for incumbents - particularly public schools - as they are forced to compete with entrants.

(3) Better matching of students with specialized schools. For example, some schools may invest into high quality arts or athletics programs, such that students with these interests are better served.

From an empirical perspective, a relevant contrast between these factors concerns the settings in which they can be studied. The first one can be analyzed in any country with a private school sector, regardless of its size. Analyzing the second requires situations in which the amount of competition observed in a given market changes substantially, for example when a large scale voucher program results in substantial private sector growth.

In this section, we summarize the evidence on effects (1) and (2) in the United States. We then discuss four developing countries that offer settings and data that usefully complement/extend this research: Chile, Colombia, India, and Pakistan. ${ }^{3}$

2.1. The Relative Performance of Private and Public Schools. In the majority of educational markets, private school students on average have higher absolute test scores than public school students. This often leads to the suggestion that private schools also have higher productivity. ${ }^{4}$ Establishing a productivity advantage in a causal sense would ideally require observing the outcomes of the same student under public and private schooling. Since this is not possible, ${ }^{5}$ the literature attempts to compare groups of students that are identical

\footnotetext{
${ }^{3}$ Due to space constraints we do not focus on point (3).

${ }^{4}$ For example, in a recent World Bank report, Patrinos et al. (2009) open their review of the literature by stating that "[t]he existing evidence from around the world shows that the correlation between private provision of education and indicators of educational quality is positive, which suggests that the private sector can deliver high quality education at low cost."

${ }^{5}$ Holland (1986) calls this the fundamental problem of causal inference.
} 
except with regard to the type of school they attended, with only a few (quasi-)experimental studies approximating this ideal.

In the United States, such comparisons have often focused upon the impact of attending Catholic school relative to attending a public school. In general, the resulting literature does not produce evidence of a consistent and substantial advantage of private over public provision. ${ }^{6}$ For example, in a recent review Neal (2009) states that: "Measured solely by achievement and attainment effects, existing evidence does not support the view that private schools are generally superior to public schools in all settings." Barrow and Rouse (2009) conclude that "[t]he best research to date finds relatively small achievement gains for students offered education vouchers, most of which are not statistically different from zero." (Table 1 presents a summary of the key empirical studies we discuss below.)

The studies that lead to such conclusions are often based upon a careful experimental design. For example, in 1997 New York City ran an experiment that randomly allocated school choice vouchers to low income students. Though the analyses of this experiment were controversial, both Mayer et al. (2002) and Krueger and Zhu (2004) agree that if one considers the entire eligible population, winning a voucher to attend private a school had a modest, statistically insignificant impact on student learning. ${ }^{7}$

There is increasing use of such careful evaluation techniques in developing country settings. We now consider the cases of Colombia and India, where there have been several good studies. $^{8}$

2.1.1. Colombia. From 1992 to 1997, Colombia operated a secondary school voucher program. A central stated goal of this initiative was to increase secondary $\left(6^{\text {th }}-11^{\text {th }}\right.$ grade) enrollment rates, using private sector participation to ease public sector capacity constraints that most affected the poor. As a result, the vouchers were targeted at entering $6^{\text {th }}$ grade students who were: i) residing in low-income neighborhoods, ii) attending public school, and iii) accepted at a participating private school.

The initiative was implemented at the municipal level, with the national government covering about 80 percent of its cost, and municipalities contributing the remainder. Resource

\footnotetext{
${ }^{6}$ In this literature the focus is mainly on determining if private schools have an advantage in terms of value added as opposed to cost-effectiveness. For a general discussion on cost-effectiveness issues in education, see Levin and McEwan (2001).

7 The controversy surrounds the effects on subgroups - the conclusion for these varies with how subgroups are defined.

8 There is of course a large literature on private/public comparisons in developing countries, one that extends beyond these two cases. As is the case in the United States, papers meet with varying success in terms of establishing credible control groups; some implement cross-sectional analyses only, others look for explicit sources of exogenous variation. For a review on several countries, see Patrinos et al. (2009). For reviews on Latin America, see Somers et al. (2004). For reviews on Chile see Bellei (2007) and McEwan et al. (2008). For work on India see Kingdon (1996), on Indonesia, Newhouse and Beegle (2006), and on Pakistan, Das et al. (2006).
} 
constraints at both governmental levels resulted in excess demand in most jurisdictions. When this happened, the vouchers were generally allocated via lotteries.

These lotteries make it feasible to estimate the causal effect of winning a voucher to attend private school. A series of papers (Angrist et al. (2002), Angrist et al. (2006), and Bettinger et al. (2008)) use them to show that, in general, lottery winners have better academic and non-academic outcomes than lottery losers. This result holds both for achievement measured using administrative data, and for outcomes (such as performance in standardized exams) that the researchers themselves measured.

This voucher program provides an excellent example of how an intervention not designed for evaluation purposes can be used to carefully measure the impact of vouchers. At the same, in terms of identifying a private test productivity advantage as defined by Hoxby (2002), the Colombian voucher experiment has a few disadvantages. First, the vouchers were renewable contingent on grade completion, and thus the program included an incentive component - voucher winners faced a stronger reward for doing well at school. Therefore, it is difficult to rule out that the superior test performance of lottery winners was due to external incentives rather than to their schools' test productivity.

Second, both lottery winners and losers tended to enroll in private schools, particularly in larger cities. Focusing on Bogota and Cali, Angrist et al. (2002) point out that while about 94 percent of lottery winners attended private school in the first year, so did 88 percent of the losers. This is not surprising to the extent that a high private enrollment rate in secondary was symptomatic of the very supply bottlenecks that the program was implemented to address. Since the reduced form estimates in these papers are based upon a comparison of lottery winners and losers, they in some cases measure a "private with incentives vs. private without incentives" effect, rather than the effect of private vs. public schooling that the literature typically addresses.

Finally, the institutional setup implies that many voucher winners (who, again, would have used private school even if they did not win the lottery) used the vouchers to "upgrade" to more expensive private schools. Specifically, Angrist et al. (2002) discuss that the maximum tuition the voucher covered was roughly equivalent to the cost of a low-to-mid price private school, and that it was common for voucher recipients to supplement this amount. Thus, part of the effect of wining a lottery could reflect the access to greater resources, as opposed to a true test productivity difference.

To summarize, these studies support the hypothesis that the Colombian voucher program enhanced student performance. However, the studies cannot distinguish between three plausible mechanisms that may explain their results: increased competition/choice, a direct effect on student incentives, and an increase in resources allocated to education. 


\begin{tabular}{|c|c|c|}
\hline Study & Sample & Key Findings \\
\hline \multicolumn{3}{|c|}{ The Relative Performance of Private and Public Schools } \\
\hline Neal (2009) & $\begin{array}{l}\text { Literature review on the effects of public } \\
\text { versus private schooling }\end{array}$ & $\begin{array}{l}\text { The empirical evidence does not suggest that private } \\
\text { schools are always superior to public schools in terms } \\
\text { of achievement or attainment. }\end{array}$ \\
\hline $\begin{array}{l}\text { Barrow and Rouse } \\
\text { (2009) }\end{array}$ & $\begin{array}{l}\text { Literature review on the effects of } \\
\text { vouchers on student achievement }\end{array}$ & $\begin{array}{l}\text { Empirical studies generally find small and statistically } \\
\text { insignificant gains in achievement for students offered } \\
\text { vouchers. }\end{array}$ \\
\hline $\begin{array}{l}\text { Angrist, Bettinger, } \\
\text { Bloom, Kremer, and } \\
\text { King (2002) }\end{array}$ & $\begin{array}{l}\text { Applicants to Colombian lotteries } \\
\text { distributing secondary school vouchers } \\
\text { from 1992-1997 }\end{array}$ & $\begin{array}{l}\text { Lottery winners were } 10 \text { percentage points more likely } \\
\text { to have completed } 8 \text { th grade and scored } 0.2 \text { standard } \\
\text { deviations higher on an achievement test. }\end{array}$ \\
\hline $\begin{array}{l}\text { Angrist, Bettinger, } \\
\text { and Kremer (2006) }\end{array}$ & $\begin{array}{l}\text { Applicants to Colombian lotteries } \\
\text { distributing secondary school vouchers } \\
\text { from 1992-1997 }\end{array}$ & $\begin{array}{l}\text { Lottery winners were } 5-7 \text { percentage points more } \\
\text { likely to graduate from high school and scored } 0.2 \\
\text { standard deviations higher on a college entrance }\end{array}$ \\
\hline $\begin{array}{l}\text { Sekhri and } \\
\text { Rubinstein (2010) }\end{array}$ & $\begin{array}{l}\text { Applicants near the cutoff score for } \\
\text { admission to public colleges in India from } \\
\text { 1998-2002 }\end{array}$ & $\begin{array}{l}\text { There is no evidence of a difference in the } \\
\text { performance of students attending public and private } \\
\text { colleges on a college exit exam. }\end{array}$ \\
\hline \multicolumn{3}{|c|}{ The Effects of Large Scale Competition } \\
\hline $\begin{array}{l}\text { Hsieh and Urquiola } \\
\text { (2006) }\end{array}$ & $\begin{array}{l}\text { Chilean municipalities affected by a } \\
\text { universal voucher scheme introduced in } \\
1981\end{array}$ & $\begin{array}{l}\text { Municipalities with faster growth in the share of } \\
\text { private schools exhibit greater stratification but no } \\
\text { increase in the growth of test scores or average }\end{array}$ \\
\hline \multicolumn{3}{|c|}{ Parents' Valuation of School Testing Performance } \\
\hline Black (1999) & $\begin{array}{l}\text { Houses on the boundary of school } \\
\text { districts in Massachusetts from 1993- } \\
1995\end{array}$ & $\begin{array}{l}\text { Parents are willing to pay } 2.5 \text { percent more for houses } \\
\text { that give their children access to schools with } 5 \\
\text { percent higher test scores. }\end{array}$ \\
\hline $\begin{array}{l}\text { Hastings and } \\
\text { Weinstein (2008) }\end{array}$ & $\begin{array}{l}\text { North Carolina households receiving } \\
\text { school test score information via natural } \\
\text { or field experiments from 2002-2007 }\end{array}$ & $\begin{array}{l}\text { Parents who receive information on school test scores } \\
\text { are significantly more likely to choose high-performing } \\
\text { schools for their children. }\end{array}$ \\
\hline
\end{tabular}

TABLE 1. Key empirical studies on the effects of competition on test productivity

2.1.2. India. The developing country literature also provides arguably causal estimates of a private/public advantage at other educational levels. For example, Sekhri and Rubinstein (2010) consider whether public universities in India have higher value added than private colleges.

This raises the interesting point that while the expectation in most developing countries is that private K-12 institutions perform better than public ones, the reverse is sometimes the case for higher education. ${ }^{9}$ This generally happens in settings in which public universities are on average older and more selective. This stacks any cross sectional comparison in their favor.

Sekhri and Rubinstein (2010) suggest that this is also the case in India, where a perception of greater productivity by public colleges has led to calls for constraining the rapid growth

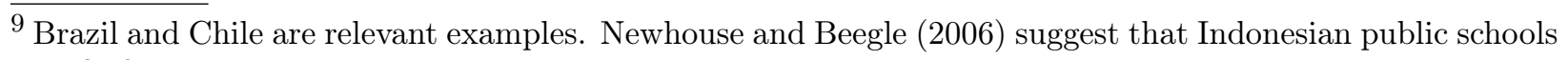
benefit from positive selection even at the primary level. 
of the private sector. For example, they point out that in 1970, 4 out of 139 engineering colleges were private; by 2006, 1,400 out of 1,600 were private.

Sekhri and Rubinstein explore whether a true public university test productivity advantage exists by using a regression discontinuity design. Specifically, they take advantage of the fact that by regulation, private colleges must affiliate with public universities to grant degrees. They must implement the same curricula and admissions and exit examinations as the public universities they associate with. The authors compare the academic performance of students who just missed gaining admission into a selective public college - and are therefore more likely to attend a private institution - with that of individuals who just achieved it. By construction, these individuals have similar admissions exam scores, and any difference in their exit exam performance is suggestive of a public/private productivity differential. This strategy produces no evidence of such a difference.

Finally, Sekhri and Rubinstein calculate the costs of these institutions, and find average costs of 13 and 13.7 thousand rupees for private and public colleges, respectively. They conclude that public colleges do not have a cost-related advantage either.

To summarize, the literature on whether there is a private test productivity advantage produces mixed results; the estimated effects do not seem to be of a regularity or magnitude such that transferring students into private schools would by itself substantially and reliably raise achievement.

This finding is consistent with a broader literature on the effects that attending a higher achieving school or class has on academic performance, even when these transfers occur within a given (public or private) sector. Here again several papers find little or no effect (e.g. Cullen et al. (2005, 2006), Clark (2010), Duflo et al. (2008), Abdulkadiroglu et al. (2011), and Dobbie and Fryer (2011)) and some find positive effects (e.g. Pop-Eleches and Urquiola (2011) and Jackson (2010)), but no uniform pattern emerges.

2.2. The effects of large scale competition. Private/public comparisons essentially address a "partial equilibrium" question: how would a given student's achievement change if she transferred from a public to a private school? In contrast, studies of generalized school choice address the general equilibrium effects of competition: e.g., what would be the effect of substantial private school entry into a market?

This is a relevant contrast because the magnitude of the private advantage may not be stable with respect to the private sector's market share. For example, Hsieh and Urquiola (2006) and Bettinger et al. (2008) point out that if the private productivity advantage originates in positive peer effects, then the magnitude of this advantage may change with growth in the private sector. This in turn reflects that the composition of the students in the private and public sector is likely to change with private entry. 
Tiebout choice (arising from the fact that many households can choose to settle in one of multiple school districts) provides the main opportunity to study large scale competition in the United States. Here again, the literature produces mixed results rather than a distinct sense that greater choice raises testing outcomes (e.g., Hoxby (2000), Rothstein (2007)). At the same time, there is evidence that Tiebout choice can lead to stratification (e.g. Clotfelter (1998), Urquiola (2005)), which combined with causal peer effects would lead to the distributional considerations treated in models like Epple and Romano (1998).

These issues also arise in developing country settings in ways that potentially productively contribute to the literature. We begin with the case of Chile, which provides one of the central examples of the application of the principles put forth by Friedman (1962).

2.2.1. Chile. In 1981 Chile introduced a universal voucher scheme. ${ }^{10}$ Prior to this reform, three types of schools were in operation: i) public schools managed by the national State and accounting for about 80 percent of enrollments, ii) unsubsidized private schools catering to upper-income students and accounting for about 6 percent of enrollments, and iii) subsidized private schools which did not charge tuition, received limited lump-sum subsidies, were often Catholic, and accounted for roughly 14 percent of enrollments.

The 1981 reform had two main components. First, it transferred public school management to municipalities, awarding them a per-student subsidy sufficient to cover their costs. Second, subsidized (or "voucher") private schools began to receive the same per-student subsidy as municipal schools.

The key elements of the reform persist to present-day and place few restrictions on private schools. These schools can be religious and can operate for profit. They are allowed to implement admissions policies subject to few regulations, and as of 1997 can charge tuition add-ons. In contrast, public schools are not allowed to turn away students unless oversubscribed, and cannot charge tuition at the primary level.

These changes resulted in substantial private school entry. By 2009, about 57 percent of all students attended private schools, with voucher schools alone accounting for about 50 percent. The latter, combined with a public share of 44 percent means that about 94 percent of all children attend effectively voucher-funded institutions. ${ }^{11}$

The analytical virtue of this reform is that it provides an example of a large-scale introduction of competition into an educational market. The main drawback is that the simultaneous nationwide implementation makes it difficult to establish counterfactuals. As a result, most studies have adopted quasi-experimental methodologies. Hsieh and Urquiola (2006) apply a difference-in-differences approach to municipalities for the 1982 to 1996 period. They

\footnotetext{
${ }^{10}$ For further institutional details see McEwan and Carnoy (2000) and Urquiola and Verhoogen (2009).
}

11 The "elite" unsubsidized private schools account for about 6 percent of enrollments. 
find that municipalities that experienced faster growth in private sector market share show distinct signs of increasing stratification (with the higher income students in the public sector moving to private schools), but do not display higher growth in test scores or years of schooling.

Even setting identification issues aside, these estimates do not isolate the effects of competition on school test productivity in the sense of Hoxby (2002). Many things were changing for Chilean schools during this period, including the distribution of students (and hence potential peer effects) and levels of funding. ${ }^{12}$ Taken at face value, however, these findings suggest competition had a modest effect on average school productivity. However, despite the use of some candidate instrumental variables, private entry into school markets is endogenous and hence there is always the possibility that the estimates are biased.

Auguste and Valenzuela (2006) and Gallego (2006) analyze cross-sectional data, using instruments for the private market share. Auguste and Valenzuela use the distance to a nearby city, and Gallego uses the density of priests per diocese (with the motivation that this lowered the costs of catholic schools). The results from both papers differ with Hsieh and Urquiola (2006) in that both find that private entry results in higher achievement, and concur (in the case of Auguste and Valenzuela - Gallego does not analyze the issue) in finding that it also leads to stratification. Again, however, a key issue is the validity of the instrumental variables. ${ }^{13}$

This research must also be considered alongside aggregate trends. If there exists a substantial private productivity advantage, then one would expect Chile's relative performance on national and international tests to have improved over the years in which large numbers of children were transferred into the private sector. Furthermore, one would expect Chile to outperform other countries with similar levels of gross domestic product per capita. Neither of these predictions receive much support in the data. Other than a recent improvement in PISA test scores,${ }^{14}$ national test scores in Chile have been largely stagnant even as educational spending has increased substantially. Privatization has thus been associated with a decline in school test productivity.

\footnotetext{
12 The value of the school voucher fell significantly during the 1980s and grew substantially during the 1990s. ${ }^{13}$ It is possible, for example, that more motivated parents migrate toward cities in search of better schools, or that priests were allocated to communities in a manner correlated with characteristics (e.g. population density) that might affect educational achievement.

14 This improvement is observed in Reading (and not in Math), and it is concentrated among low income children, who predominantly attend public schools. Given the numerous reforms that have occurred in Chile over the past two decades (e.g., compensatory funding for schools with low income students, accountability initiatives, teacher pay reform, early childhood programs etc.) it is difficult to attribute this change to a particular intervention, let alone to the introduction of school choice three decades back.
} 
Finally, Bravo et al. (2010) analyze the effect of Chilean reform not on test scores but on graduation rates and wages. ${ }^{15}$ Specifically, they use retrospective survey data to estimate a dynamic model of school attendance and work decisions. The impact of the reform in this case is identified using differences in the schooling and work choices of individuals who were differentially exposed to the voucher system - i.e., individuals from different cohorts were exposed to different amounts of educational competition. They find that the voucher reform increased primary and high school graduation rates by 0.6 and 3.6 percentage points, respectively. They also find it did not increase average earnings.

In short, the research on the effect of large scale school choice reforms on average outcomes in Chile produces mixed results. In contrast, there is robust evidence that competition resulted in increased stratification by family background and ability. These results are generally consistent with the consensus within Chile (as articulated recently by the country's conservative President Piñera) that the school choice system "perpetuates inequality," and has not done enough to raise learning. This is in marked contrast with Chile's track record of success with market-oriented reforms in many other sectors of the economy.

2.2.2. Pakistan. The cases of Chilean and Colombian K-12 schooling, and Indian higher education, illustrate situations in which the use of private institutions takes place in middle income settings and with significant state subsidies. However, developing countries also provide settings in which private schools enter and compete unaided in low income markets. These cases are frequently more challenging to study, if only because the necessary data are not as readily available.

Andrabi et al. (2008) document substantial growth in private enrollment in four large provinces in Pakistan during the 1990s. For example, they find that private enrollment grew from 4 to 6 percent in Balochistan, and from 15 to 30 percent in Punjab. This expansion took place in both urban and rural areas. The result is that "by the end of the 1990s, nearly all rich Pakistani children in urban areas, almost a third of the richer rural children, and close to 10 percent of children in the poorest deciles nationally were studying in private schools." 16

Andrabi et al. (2008) emphasize that this growth is not due to an expansion of religious schools (e.g. Madrasas), but rather reflects an expansion in for-profit institutions that charge

\footnotetext{
15 The latter is an outcome we focus on below; we cite the results here but return to this aspect of the study below.

16 This is certainly not the only case of large scale unsubsidized private school entry in low income areas. For instance Kremer and Muralidharan (2006) point out that about 25 percent of children in rural India have access to fee-charging private schools. There is less data on such low-cost private schools in Latin America, but the anecdotal evidence is certainly consistent with a significant role for them, particularly in poor urban neighborhoods.
} 
low fees - a typical village private school in these provinces charges about 18 dollars a year. ${ }^{17}$ These schools achieve extremely low costs by hiring young, single, untrained local women as teachers and paying them much less than the certified teachers more common in public schools. $^{18}$

These observations imply that Pakistan could in fact buy education for much lower cost if it further shifted enrollments to the private sector. Would theses savings come at a cost of lower educational attainment? "Not necessarily," according to Andrabi et al. First, they note evidence by Das et al. (2006) suggesting that an estimated private school test advantage persists in Pakistan even after controlling for child, household, and community characteristics. Andrabi et al. point out, however, that this result relies on less solid empirical identification than, for example, the studies on Colombia reviewed above.

In summary, Pakistan illustrates that in much of the developing world, private schools can enter and provide competition even without state support. As in the case of Chile, private entry is associated with significant stratification (as suggested by the authors' broad description of the users of these schools, cited above) but need not result in lower achievement. Andrabi et al. (2008) highlight the potential limits to such expansion. A notable one is that private entry has mostly occurred at the primary level. Secondary education would require for-profit private schools to hire trained teachers, driving their costs up significantly.

To summarize the contents of this section, the evidence from developing countries suggests that large scale expansions of the private school sector lead to stratification, ${ }^{19}$ but there is less evidence that they lead to substantial gains in average school productivity. This is consistent with the lack of a systematic private school advantage referenced above, and additionally suggests that the introduction of competition may not by itself have a large impact on public school productivity.

2.3. Other pieces of the puzzle. Overall, the evidence is, perhaps surprisingly, not strongly supportive of Friedman's hypothesis that parental concern for school quality, combined with schools' concern for their reputation, implies that increased competition would produce substantial improvements in school productivity.

This result is even more surprising given the evidence that parents value school testing performance. For example, Black (1999) uses U.S. data and quasi-experimental methods to show that households are willing to pay more for houses that give them access to schools with higher test scores. ${ }^{20}$ In an experimental setting, Hastings and Weinstein (2008) show

\footnotetext{
${ }^{17}$ See also Alderman et al. (2001).

18 Andrabi et al. note that the fact that these women are often high school graduates from public schools is one way in which the public sector indirectly supports the private sector.

${ }^{19}$ For other examples of school market liberalization leading to stratification see Bjorklund et al. (2005) and Mbiti and Lucas (2009) for the cases of Sweden and Kenya, respectively.

${ }^{20}$ See also Fack and Grenet (ming).
} 
that parents react to information on school performance by requesting higher-scoring schools. While the developing country literature does not provide such direct evidence, households in many countries (including Chile, Colombia, and Pakistan, as discussed above) are willing to leave the public sector to move into private schools with higher absolute outcomes, often at substantial cost to themselves.

This willingness to pay for schools with higher absolute achievement - combined with the evidence reviewed earlier in the paper-suggests that in many cases parents prefer such schools even if they do not provide higher value added (e.g. Abdulkadiroglu et al. (2011) present direct evidence of such behavior in Boston and New York). The question then is why are parents so eager to access selective schools given the paucity of evidence that they provide higher test productivity?

As emphasized by Hoxby (2002), the standard explanation has centered on peer effects. Positive human capital spillovers would warrant a preference for higher performing schools even if these do not supply higher value added. Two problems immediately arise with this explanation, however.

The first is simple but often not appreciated. It is that human capital spillovers are conceptually and empirically part of a school's value added. When papers like Cullen et al. (2005), Clark (2010), and Sekhri and Rubinstein (2010) produce a reduced form estimate that suggests no benefit to attending a higher achievement school, this estimate includes peer effects. If academic peer effects are truly positive, then these schools may have even lower value added than the lower absolute achievement schools that families so eagerly pay to escape. Since the higher achievement schools are often more expensive, they could be of substantially lower productivity.

Second, the direct evidence on the significance and magnitude of peer effects is mixed and often suggests these are small (Oreopoulos (2003), Katz et al. (2006), and Angrist and Lang (2004)). In a recent study Carrell et al. (2010) directly control classroom composition as a function of student performance. They find no reliable effect of peer group composition on student performance.

2.4. Where is empirical research 50 years after Friedman (1962)? Five decades after Friedman's seminal work on school choice, economists do not have a full understanding of the impact of private participation and competition on the performance of educational markets. The evidence thus far is mixed. When it comes to policy in developing countries, this stands in stark contrast to our more successful policy interventions, such as, in many cases, using privatization to enhance the performance of the telecommunications sector. 
Another way of seeing that competition has not produced the desired results is by taking stock of where empirical economic research on education is today. Two topics receiving a great deal of attention are:

(1) Randomized evaluations of educational interventions, and

(2) The design and implementation of methodologies to identify and reward/terminate especially effective/ineffective teachers.

Neither of these approaches is particularly consistent with Friedman's market and incentivecentered approach. Underlying Friedman's idea is the theme that bureaucrats (and perhaps researchers) might not be able to discover how to improve education, but that given the right incentives, market actors would do so. Hanushek (1995) articulates this view: "My own interpretation of the existing evidence ... is that schools differ in important ways, but we cannot describe what causes these differences very well." Given this perspective, Hanushek argues for providing incentives and letting market actors figure out the production function: "Performance-based policies are those that reward accomplishment-such as good reading skills or adequate numeracy skills. These policies would specify end goals, provide carrots and sticks related to them, and harness the energies of the actors in the system, but they would not specify how individual schools would achieve these goals."

In contrast, in his review of approach (1), Banerjee (2007) calls for economists to "step into the machine"- to enter schools and discover the specifics of the educational production function. In advocating for this planning approach, Banerjee (2007) explicitly criticizes Friedman's market and incentive-centered approach: "To those who believe in it, the word 'incentives' is an abstraction, a metonymy for faith in the power of the market. They do not claim to know how exactly the market will achieve the promised miracle, but it will do it (indeed for them this unpredictability is part of the appeal)." To summarize, by calling for economists themselves to use randomization to discover the educational production function, Banerjee suggests an approach manifestly distinct from letting markets figure out the best course of action.

Similarly, in presenting explicit recipes regarding when/how teachers should be hired and fired, Hanushek (2010) differs from an approach that would leave such decisions to incentivized principals or private school owners. This is obviously not how other competitive markets are designed. For example, it would be considered heavy handed for government to dictate when/how restaurants should fire line cooks.

It might be the case that the focus on randomization and teacher hiring/firing is in response to the difficulty of implementing competition, due to political and other constraints. Yet, at least in the case of Chile, randomization and teacher accountability remain central 
to the current academic/policy discussion, despite massive privatization. Thus, we conclude that the continued interest by economists in carrying out randomized evaluations and teacher-related interventions reflects that simply liberalizing the market has proven to be disappointing.

\section{Incomplete Markets, Incomplete Contracts, And Incomplete Knowledge}

In this section we trace the intellectual history of some important ideas in modern Economics that are necessary for building a sound economic theory of the market for education. We shall show that, in light of these ideas, Friedman's case for free markets cannot be directly justified by an appeal to economic theory. Rather, we suggest that the theory is consistent with the desirability of a regime of managed competition, a ubiquitous feature of all complex markets in advanced market economies.

Our story begins with some foundational contributions dating as far back as the 1950s. These include:

(1) General equilibrium theory (Arrow and Debreu (1954) and Debreu (1959)),

(2) Game theory (Nash (1951) and Luce and Raiffa (1957)),

(3) Decision theory (Savage (1954)).

This work is technical and, to many, even esoteric. However, the ideas from these contributions are the foundation of modern graduate economics training, and even if not always acknowledged, form the intellectual framework within which economists view the world. ${ }^{21}$

We show that if one takes this research seriously, then there is little reason to expect school choice to enhance school test productivity - in the end it comes down to Charlie Munger's observation (in the quote opening this chapter) that we continually underestimate the power of incentives. Specifically, in this section we review each of these three contributions, discussing how it might suggest that the empirical findings discussed above are not surprising. In Section 4, we describe a model that brings these ideas together, and show that it is consistent with much of the evidence we have discussed.

3.1. What is a commodity? Let us begin with general equilibrium theory. The first welfare theorem states that when markets are complete, a competitive equilibrium is efficient. This result does not deal explicitly with the problem of distribution. This is addressed in the second welfare theorem: If markets are complete, and the production technology is "convex," then every efficient allocation can be achieved with a competitive equilibrium after the

21 This work shows that the concepts that are used daily in Economics, such as free markets, opportunity cost, the irrelevance of sunk costs for current decisions, market equilibrium, risk, rational expectations, and so on can be placed into a coherent and unified mathematical framework. This, we suggest, explains in part why the economic mode of reasoning has been so powerful in policy debates. 
appropriate redistribution of resources. In principle, there is no tension between efficiency and equity.

One can see immediately that Friedman's idea of introducing competition via vouchers has its root in the second welfare theorem-school vouchers can be used to appropriately redistribute income, while the market efficiently supplies education services. These results explicitly depend upon the existence of complete markets and a convex technology (essentially, there are no economies of scale or other frictions). Education services do not even come close to satisfying either precondition.

First, consider the complete markets assumption carefully defined in Debreu (1959) (Chapter 2). At a minimum, it must be possible to price every commodity that is in the market. Technically, a commodity is a good or service that is delivered at a specific time and place, and conditional upon the state of the world at that time.

The first question is what exactly "education" is - what is being supplied to the buyer? In Labor Economics, education is measured by the number of years of consumption of this service. Yet in practice education consists of many distinct services and goods, including listening to lectures, making presentations, working on assignments, receiving grades as a function of performance, and so on. If one were to use the Arrow-Debreu model (and apply the associated welfare theorems), then each of these various components would have to be measured and priced.

One might argue that these are details for technical nitpicking; however, parents do care about such details, and the fact that they are not priced explains many observed behaviors. For example, parents who use a given school often form a preference regarding specific teachers, and sometimes lobby to get their children assigned to them. If a teacher's performance is lacking, then parents may file a complaint with the principal. If the market were truly competitive, each teacher-class combination would be priced, and there would be an equilibrium where the teacher-class price would be set so parents were indifferent between the available options. ${ }^{22}$

The fact that there is politicking and lobbying is a natural consequence of market incompleteness. Williamson (1975) makes this point explicitly, and uses the general term "transactions cost" to denote the reason why organizations such as firms and schools use non-market mechanisms to allocate resources. One may view the move towards more school choice as an attempt to make the market more complete, which one might expect to lead to enhanced performance. This is not generally correct, however. As shown in Hart (1975),

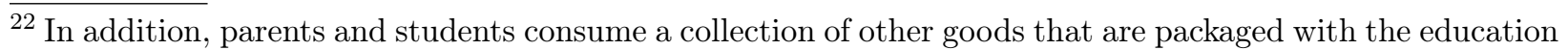
services, including after school programs, the quality of the physical plant and so on. In a competitive market, each of these would be priced. 
not only is a competitive equilibrium with incomplete markets not necessarily efficient, but making the market more complete by allowing ex post trading can make things worse.

The second welfare theorem also supposes that the technology of production is "convex"essentially there are no economies of scale. In practice, education is rife with fixed adjustment costs - costs that Williamson (1975) has identified with large potential market failures. In a paradigmatic competitive market, consumers can easily change their choices over time. This is not the case with schools. For starters, the best schools ration supply. Moreover, if one month into the academic year a student discovers that her school is substandard, she might have to wait until the end of the year to switch. Changing schools mid-year is costly, and not feasible for many parents.

To summarize, the welfare theorems show that if markets are complete, then one can use the market mechanism to achieve an efficient and equitable allocation of resources. However, not only are markets in general incomplete, there is no known result - either theoretical or empirical - that proves that making a market more complete by allowing free entry and reducing price controls will necessarily improve performance.

What is the School's Obligation? Friedman (1962) anticipated many of the observations we have made regarding the fact that the market for education is incomplete. What he claimed was that free entry and competition would still enhance outcomes because schools would develop reputations for quality that would discipline their behavior. However, a reputation is nothing more than the market's belief regarding the quality of the good that a school is producing. A necessary condition for the efficient operation of a market is that parties can enter into a contract with a well-specified performance obligation, the breach of which leads to a loss in reputation or damages (MacLeod (2007)).

Hoxby (2002) introduces a clear definition of a school obligation-namely, producing an increase in test scores at an agreed upon cost. More productive schools either have better test score performance at the same cost, or the same performance at a lower cost. If test score gains are indeed the output that parents wish to achieve, then the natural way to do this is to have a contract with the school that sets test score gains as an explicit product that the school is expected to deliver. The contract would specify damages for failing to meet this obligation, and at the end of the year the school would simply pay out to parents whose children did not achieve the agreed upon improvements.

Such a contract would lead to obvious incentives to game the system. At the end of a year, parents would have a financial interest in having their children perform poorly in exams, regardless of their actual learning during the year. Further, test scores are noisy and only imperfectly controlled by schools (e.g., Kane and Staiger (2002) and Chay et al. (2005)). One can create systems that control for this behavior and improve the precision of test scores, 
but one cannot escape from the fundamental problem that any school performance measure that is not directly controlled by the school can be gamed.

More generally, as MacLeod (2007) emphasizes, a well-designed contract imposes obligations that are easy to observe and under the control of the agent who has the obligation. In the case of education, the school can control the curriculum, the qualifications of teachers, school hours, amount of homework and so on. ${ }^{23}$ Many jurisdictions, such as New York City, have experimented with systems that reward test score productivity, ignoring these other measures. Yet there is little evidence that these experiments have been successful. This finding is consistent with the more than 100 years of evidence on compensation systems.

3.2. Strategic Behavior. When markets are incomplete, firms/schools have incentives to make strategic product choices. The industrial organization literature, having long recognized this point, contains an extensive literature on product differentiation. This research builds upon the second theme from the 1950s - the use of Nash equilibrium to model choice behavior. ${ }^{24}$ This approach yields several insights.

Suppose schools competing with each other choose the bundle of services to sell taking as given the bundles provided by other schools. The literature identifies two strategies they might follow, both of which complicate the link between free entry/competition and increased productivity.

The first is horizontal differentiation. This involves characteristics over which parents are not unanimous in their preferences. For example, some schools may emphasize sports, while others focus on academics or music. A particularly important characteristic in Education is location-parents often prefer schools that are close to their homes. Spence (1973) and Dixit and Stiglitz (1977) introduce a model of "Chamberlinian competition" and show that with strategic product choice there may be too few or too many products in the market. Another example is the popular model of product choice on a line due to Hotelling (1929). An interesting feature of this model is that if the world has well defined boundaries, and firms can choose price and location, then in some cases firms all crowd in the middle of the market, leaving students away from the center poorly served. ${ }^{25}$

Second, there is vertical differentiation, where firms sort in terms of quality (Gabszewicz and Thisse (1979)). Below we will describe a model we have developed (MacLeod and

\footnotetext{
${ }^{23}$ A nice example of an enforceable contract that produces skill acquisition is the apprenticeship contract. See Malcomson et al. (2003) on how this contract is designed to achieve an efficient skill acquisition.

${ }^{24}$ See Tirole's (1988) classic text for an illustration of the power of game theory for understanding market structure.

${ }^{25}$ D'Aspremont et al. (1979) showed that for such a model there does not exist a Nash equilibrium in prices (a result that MacLeod (1985) generalized to the multi-product case that is particularly relevant for schools). Existence would be restored if schools could collude on prices, in which case the market equilibrium would be characterized by schools moving to the center of the preference distribution and earning rents, leaving students with specialized needs under-served.
} 
Urquiola (2012)) showing that when schools can vertically differentiate through their admissions policies, then a competitive equilibrium need not be efficient. Moreover, increasing private participation may have ambiguous consequences on skill accumulation. Before turning to that illustration, we discuss a few more points related to strategic behavior.

3.3. Expectations and Hope. Let us move from the issue of the supply of educational services to the issue of student demand. In general, education is a multi-product good, of which test score performance is only one dimension. Parents also care about the physical attributes of the school, dress codes, athletic programs and so on. This implies that expanding school choice might raise parents' and students' welfare because they obtain more of a commodity they desire; it does not imply that test scores will necessarily increase.

Further, a test score is merely a signal that many parents hope is correlated with future labor market success, as emphasized in the labor economics literature. In this case, parents, and perhaps policy makers, should focus on schools' wage as opposed to test productivity. It is difficult to measure wage productivity, but we are seeing some progress. Bravo et al. (2010) examine the impact of the Chilean school reform on wages and find that while the reform slightly reduced inequality, it had little effect upon lifetime earnings.

To illustrate the notion of wage productivity, let $\hat{w}_{A}(x, A)$ be the average wage of a person of age $A$, with $x$ years of schooling. Then the return to an additional year of schooling is $r(x, A)=\frac{\hat{w}_{A}(x+1, A)-\hat{w}_{A}(x, A)}{\hat{w}_{A}}$. From this the wage productivity would be: ${ }^{26}$

$$
W P(x, K, A)=\frac{r(x, K) \hat{w}_{A}}{K}=\frac{\hat{w}_{A}(x+1, A)-\hat{w}_{A}(x, A)}{K},
$$

where $K$ is the cost of the additional year of schooling. This is the increase in income due to an additional year of schooling, divided by its cost.

Despite the work of Bravo et al. (2010) and studies like Card and Krueger (1992), measuring a concept like wage productivity at the level of individual schools - a precondition if parents are to evaluate schools based on such a measure - is very difficult. This point is emphasized by Speakman and Welch (2006), who review attempts to measure the relationship between school quality and future wages. They conclude that there are serious problems associated with establishing such a link, and hence parents and students have no reliable way to assess the causal impact of school quality on future labor market outcomes. If so, how can students and parents rationally choose a school?

This is where the third major contribution from the 1950s is relevant. Savage (1954) introduced the idea that the first step when making a rational choice is to build a model

$\overline{26}$ It is worth observing that we are measuring productivity only with regards to the pecuniary cost of education. A more complete measure would also include the disutility/cost of attending school, as in the Spence (1973). Even though individual effort does play a role in the theory, since it is not easily measured it plays no role in traditional measures of school performance. 
of the future. In particular, even if there is little evidence, rational individuals will form subjective probability assessments that link current actions to future outcomes. Without such beliefs, decisions would just be noise.

In the context of education: How should a parent evaluate the consequences of attending a particular school? The algorithm that many parents (at least the authors of this piece) use is to see how the previous graduates of a given school performed: Did they go to college? Are they now "successful"? Do they exhibit "good" behavior? This is rough and ready, but it is nonetheless based upon concrete evidence. As a result, parents and students may place weight upon tangible evidence that comes from peer success at a school. Given that there is no easy way to relate marginal test score performance to future "hopes and dreams," they are unlikely to respond to such signals.

Notice that employers are likely to use similar algorithms - for example, college recruiting firms explicitly target campuses where they have had previous success. In Section 4 we describe research (MacLeod and Urquiola (2012)) that makes these ideas more precise and, again, shows that if competitive firms use the reputation of a school an employee attended to assess her quality, then competition may not necessarily raise test score levels.

There is an important caveat. Here we have assumed that test scores are merely a measure of student learning. In some countries, there are real labor market consequences to test score performance. For example, China, France, Romania, Singapore, and Turkey have national exams whose results are published and have real consequences for higher education and labor market outcomes. Both Bishop (1997) and Woessmann (2007) suggest that these jurisdictions outperform others in terms of test score productivity, although making causal assertions in this area is difficult.

These observations are consistent with the hypothesis that what is driving school demand are expectations regarding future outcomes. When test scores and future labor market outcomes are more tightly linked, then individuals respond. When they are not linked, then individuals respond to other measures of future performance, such as the past outcomes of peers at one's school. ${ }^{27}$ It is these expectations writ large, balanced against the many other amenities supplied by schools, that drive school demand.

3.4. Compensation policies. Before proceeding to an illustration of these ideas we touch upon compensation policies. Taylor (1911) is often regarded as the father of modern management science. He observed closely the behavior of manufacturing workers and found that in many cases employment was inefficient. By this he meant that the firm would like to pay the workers more for higher output, and at the same time the workers themselves

${ }^{27}$ See also recent work suggesting that the schooling choices of individuals in developing countries respond to changes in the perceived wage returns to schooling, e.g., Jensen (2010) and Oster and Millett (2010). 
would agree to work harder for the increased compensation. These findings suggested that a pay-for-performance system would be Pareto-improving.

Implementing performance-pay systems has proven to be extraordinarily difficult. The fundamental issue is that mechanical performance-pay systems are almost always subject to some form of gaming. In what has become a business school classic, Kerr (1975) documents several examples of failed incentives systems. The problem is not that individuals do not respond to incentives - quite the contrary - they respond too readily. Thus, Kerr points out that many organizations claim, or hope, to be rewarding B when in fact they are rewarding A. For example, universities often stress the importance of teaching. Yet, compensation is typically linked to a person's outside opportunities, which, for most academics, is more closely related to research rather than teaching performance.

In a recent analogous example, Reback (2008) documents that schools strategically respond to accountability systems that specify minimum competency requirements (e.g. systems that measure the proportion of students who pass a given statewide test). Schools focus their effort on students who are close to the passing score, diverting it away from, for example, students who will clearly score above it.

More generally, there has been extensive research on pay-for-performance systems in the hope of reducing the inefficiencies Taylor (1911) noted. The National Academy sponsored a study in 1991 (Milkovich and Wigdor (1991)) exploring the extent to which performance pay could be used to enhance government. They concluded:

"The search for a high degree of precision in measurement does not appear to be economically viable in most applied settings; many believe that there is little to be gained from such a level of precision. The committee concludes that federal policy makers would not be well served by a commitment of vast human and financial resources to job analysis and the development of performance appraisal instruments and systems that can meet the strictest challenges of measurement science. The committee further concludes that, for most personnel management decisions, including annual pay decisions, the goal of a performance appraisal system should be to support and encourage informed managerial judgment, not to aspire to the degree of standardization, precision and empirical support that would be required of, for example, selection tests."

Despite this skepticism, there has been increased interest in implementing performance pay systems for teachers. For example, the U.S. Department of Education has introduced a fund to encourage states to measure and reward teacher performance (the Race to the Top 
Fund). ${ }^{28}$ Recently, the National Academy returned to the issue of performance pay with particular attention to teacher compensation (Hout and Elliott (2011)). The conclusion:

"Our review of the evidence uncovered reasons to expect positive results from incentive programs and reasons to be skeptical of apparent gains. Our recommendations, accordingly, call for policy makers to support experimentation with rigorous evaluation and to allow mid-course correction of policies when evaluation suggests such correction is needed."

This nuanced view is consistent with a century of experimentation with performance pay systems. MacLeod and Parent (1999) document the use of performance pay in the U.S. economy, finding that performance pay is explicitly used in about 30 percent of jobs. Its use is highly correlated with job characteristics: the incidence of performance pay is much higher for jobs for which there is a clean, unambiguous measure of performance. This is particularly evident in sales, where revenue is often a good measure of a sales-person's productivity.

If there are significant subjective elements to employee performance, then explicit performance pay is not a silver bullet. Holmström and Milgrom (1991) highlight the fact that if one can only measure a single dimension of individual performance, then rewarding only that element can distort behavior away from the efficient solution. If there are differences of opinion regarding what constitutes good performance then the optimal contract is either flat, or else there is increased conflict between management and employees as one increases the link between measured performance and pay (MacLeod (2003)).

In the case of education, one should keep in mind that test scores are diagnostics, and not goals in and of themselves. They measure a student's command of information that is correlated with the ultimate goal - namely, obtaining meaningful employment in the future. The fact that many educators focus upon test scores, while students care about future employment, helps explain why educators and students/parents may not always agree on the way forward.

\section{An illustration}

In recent work we attempt to provide a concrete illustration of the ideas raised in Section 3. To do so, we add elements of industrial organization and labor economics to the more Public Finance-focused theory of school choice. Specifically, in MacLeod and Urquiola (2012) we construct a model in which students go to school, acquire skills, and then work in a competitive labor market.

4.1. Setup. Relative to the existing literature the model has three key novel ingredients:

${ }^{28}$ See http://www2.ed.gov/programs/racetothetop/index.html. 
(1) Students have to exert effort to accumulate skill. Although student effort has not been a focus of the literature, Bishop (2006) has emphasized its importance; student learning is a joint product of school and student inputs. Moreover, it is clear from cross-country evidence that societal levels of educational effort display wide variation. Dang and Rogers (2008) illustrate such variation in their review of evidence on private tutoring industries that exist in many countries. For example, Korean households spend 2.9 percent of GDP on private tutoring, which approaches the 3.4 percent the public sector allocates to education. In Turkey, private spending similarly approaches the public effort. Tutoring expenditures have been growing quickly in Canada, Kenya, and Vietnam. ${ }^{29}$ Finally, there is growing empirical research on interventions to elicit effort (see for instance Angrist et al. (2009) and Kremer et al. (2009)).

(2) Schools have reputations given by their graduates' expected skill. Since Spence (1973), the idea that an individual's years of schooling can signal her ability has been standard in Labor Economics. We introduce school reputation to capture the idea that conditional on years of schooling, the identity of the school a person attended can provide the market with information regarding her ability. This is consistent with research on Colombia (Saavedra (2009)) and the United States (Hoekstra (2009)) that uses regression discontinuity designs to show that school identity/prestige has a positive effect on wages - upon entry into the labor market and about five years later, respectively. ${ }^{30}$

(3) The school sector is perfectly competitive in that private schools with selective admissions and different levels of value added are free to enter. We assume educational systems consist of a continuum of schools, each of which contains a continuum of students. We thus abstract from small numbers problems, which differentiates our model from earlier work on school choice, such as Epple and Romano (1998). These models focus on monopolistic competition where there is an efficient scale for schools, and hence each school has some market power. Conceptually, such a setup supposes that the number of schools is fixed in the short run, and that students select into schools (see Nechyba (2006) for a general discussion of this class of models). Our concern, rather, is with understanding the implications of perfect competition in the presence of reputation effects.

\footnotetext{
${ }^{29}$ For other work on how the presence of a private tutoring industry affects incentives in the public sector, see Jayachandran (2008).

${ }^{30}$ Dale and Krueger (2002) find no effect of school selectivity on wages about 20 years after graduation. Note, however, that all three studies could be consistent with an impact of school selectivity on starting wages, since a Bayesian framework would predict this effect would become attenuated over time as the market gained more information on individuals' ability - this is in fact the prediction of the model we describe below.
} 
Thus, the model incorporates elements of test productivity, wage productivity, school reputation, and parental demand, factors that are central concerns of the literature we have reviewed.

The model has two periods. In the first, student innate ability is realized when individuals are born, but it is not directly observed. Ability can only be revealed once an individual learns and engages with the world. When this happens, individuals, schools, and the labor market observe signals that lead them to update their beliefs regarding individual ability.

One such signal is family background, observed by all agents. ${ }^{31}$ Another is an admissions test observed by individuals and schools prior to enrollment. This measure is soft information that is not verifiable by employers.

Schools select admissions policies that, to different extents, exploit the admissions test and family background; these policies are public information. Schools also set their value added. Students then choose among the set of schools that have offered them admission. They also make consumption choices and decide how much effort to allocate to study. Finally, student skill is realized as a function of three factors: i) student innate ability, ii) student effort, and iii) school value added.

In the second period, students graduate and enter the labor market. The market observes two signals of individual skill:

(1) The identity/Reputation of the school attended by each student; when schools are selective, this provides a signal of the student's innate ability. We suppose that no given individual can (through her own effort) affect her school's reputation. Intuitively, this reflects that in reality a school's reputation is based on the characteristics of multiple cohorts of graduates, and no single person can easily manipulate such a measure.

(2) An individual-specific measure of skill we term a graduation test. As its name indicates, this measure can be motivated using the highly publicized standardized high school graduation or college entry exams in countries such as Germany, Romania, South Korea, and Turkey. Other individual-specific measures are seen in other settings and educational levels. For example, in the United States college graduates distribute letters of recommendation and lists of honors received, while Economics Ph.D. students distribute "job market papers." Finally, in contrast to her inability to affect her school's reputation, we assume that through her effort a student can directly affect her graduation assessment.

$\overline{31}$ There is evidence that family background provides some information regarding a person's likely future ability (Almond and Currie (2011)). 
The labor market sets wages equal to expected skill given these two signals. To summarize, we situate an analysis of school system test productivity (how much learning is produced for a given level of resources) in a context in which individuals and schools respond to incentives.

In this setup we have focused upon signals of ability that follow from family background, an assessment that takes place before students apply to school, and an assessment given immediately upon graduation. In practice, the evaluation of an individual's ability is an ongoing process. What is important, and we feel realistic, is that no test or assessment is perfectly predictive of future ability.

For example, the background of American presidential candidates is carefully scrutinized, yet there still seems to be a great deal that one learns about their ability after they get the job. Our Economics department has an analogous discussion during each graduate admissions round - we have plenty of information on individuals' test scores, but these signals are only imperfectly correlated with a student's future ability for research.

Our graduate students realize this, and so even if they do not have the top test scores, they can still hope to make significant contributions to research. However, they cannot do so if they do not get admitted to graduate school. Moreover, getting into a more prestigious graduate program means that they will have a step up in the job market. This in turn means that they do care about a program's reputation, and all else equal would want admission to the most prestigious department possible. We now turn to the implications of these observations for school choice.

4.2. Implications: The anti-lemons effect. The first result from our setup is that parents/students will prefer schools with better reputations - they will value selectivity and better peers per se. Due to signaling concerns, students will prefer schools with higher achievement even if this advantage does not originate in higher value added or positive peer effects (indeed, our model does not even feature the latter).

This result can reconcile three observations highlighted in Section 2: i) there is clear evidence that parents prefer higher achieving schools, ii) the evidence on whether higher achieving schools produce higher value added is mixed, and iii) the evidence on the significance and magnitude of peer effects is also mixed. Note that in our model the concern for peer quality emerges endogenously - students will wish to attend schools whose graduates have been successful in the past. As previewed above, this highlights a contrast with earlier theoretical work on school competition by Benabou (1996) and Nechyba (2000), which also predicts stratification; in these models sorting originates in unpriced peer externalities.

A second set of results concern the impact of private entry and competition on the system's performance. These follow from an anti-lemons effect that arises when firms (schools) can 
influence their reputation by positively selecting their buyers (students). Specifically, in MacLeod and Urquiola (2012) we show:

(1) All else equal, competition will raise school productivity, capturing Friedman's (1962) intuition. However, this need not always be the case. In some situations, students will prefer a school with lower value added, provided its reputation (due to an outstanding peer group) is strong enough. In such settings, increasing choice and competition may actually lower average school productivity. ${ }^{32}$

(2) Private entry may have detrimental effects on effort, and therefore on skill accumulation. Suppose there is a system that originally consists of non-selective public schools (i.e., of schools that essentially admit applicants at random). Now consider the entry of selective private schools (i.e., schools that admit based on students' performance in the admissions assessment) into this setting. This will tend to lower student effort among the students who attend such schools. This is a straightforward application of Holmstrom (1999). The intuition is that as selectivity increases, school reputation provides a more precise signal of student skill. As a result, the extent to which an individual is able to affect the market's assessment of her skill through the one signal she can affect - the graduation test-falls, and hence so does the incentive to study. This implies, for example, that if the introduction of school choice results in stratification, then it might not result in large academic achievement gains. The prediction that school selectivity lowers effort is also consistent with anecdotal and circumstantial evidence on student behavior. For example, students in Japan work very hard to get admitted to elite schools like the University of Tokyo, yet those who are successful are said to dramatically lower their effort once there. In the United States, Hoxby (2009) shows that the selectivity of colleges has increased over the past decades, while Babcock and Marks (2010) document that during this same period, the amount of time spent studying declined from 40 to 27 hours per week.

(3) The entry of private selective schools has adverse effects on the effort of students who remain in the non-selective sector ${ }^{33}$ - an illustration of the effect of stratification on student hope and aspirations. ${ }^{34}$ The intuition is that the students left behind in these schools are revealed to the labor market as being of lower ability. By a logic similar to that in the previous point, they therefore have a lower incentive to signal their skill via the graduation test. Individuals left behind in the non-selective public

\footnotetext{
${ }^{32}$ For example, this case can arise if the government constrains the number of schools, as happens in many jurisdictions.

${ }^{33}$ In MacLeod and Urquiola (2012) we show an equilibrium exists where selective private and non-selective public schools coexist.

${ }^{34}$ Coate and Loury (1993) make a similar point about the negative effect of racial stereotypes. Austen-Smith and Fryer (2005) shows that behaviors, such as "acting white," can be viewed as signaling phenomena.
} 
schools find that their peers are less successful than the students from more selective schools, and this lowers their motivation. This result is a natural consequence of a Bayesian framework in the spirit of Savage (1954). Note also that social learning research indicates that peer success is salient for individuals when forming beliefs regarding their future (Bandura (1986)).

These predictions are consistent with cases in which independent schools are subsidized and allowed to be selective. As described above, in 1981 Chile implemented school choice in a manner that fits our framework. Consistent with our predictions, private schools entered by cream-skimming, enrolling the wealthiest children. Further, the private sector itself is highly stratified. For instance, Mizala et al. (2007) show that the identity of the school a child attends is a good predictor of her household income. Meanwhile, the market share of the private sector has grown - particularly in urban areas, the public sector accounts for a distinct minority (20 or 30 percent of enrollments in some cases), and is composed primarily of the lowest-income students.

More generally, our model implies that educational markets will display a strong tendency towards stratification - in fact there is no equilibrium to the simple framework described above if only non-selective private entry is allowed. This suggests that schools will rationally try to engage in some kind of selection as a means of securing a market niche. Consistent with this notion, even in cases in which selection by independent schools is not allowed, one sees that it emerges in different ways.

For example, in the United States most states require that charter schools select by lottery if oversubscribed. But even in this context, there is anecdotal evidence that some charter schools (potentially for quite understandable reasons) engage in selection within the constraints imposed by the law. For instance, the well-known KIPP academies require that parents and students sign certain participation commitments to apply (for example, students may have to commit to attend schools on Saturdays, or parents to take part in PTA meetings). The result is that at least in terms of motivation these schools are not equivalent to the public ones they compete with. Similarly, in the case of Sweden, independent voucher schools operate under similar selection restrictions as U.S. voucher schools. Yet Bjorklund et al. (2005) conclude that their entry increases segregation across schools, as immigrants and children with highly educated parents are more likely to enroll in them.

This analysis suggests that selection/stratification may be a central feature of stable education markets. For example, the U.S. higher education market features substantial private participation, and also substantial stability; the group of institutions that comprise the top 20 universities or colleges changes little over time.

Finally, one way to mitigate the negative impact of private entry - and more generally raise educational systems' performance - is by raising the precision of individual-specific measures 
of skill, as emphasized by Bishop (2006). Consistent with this idea, Woessmann (2007) points to a country-level correlation of standardized graduation or college admissions exams and international test performance. In anecdotal evidence, few observers disagree that such high stakes examinations result in high levels of student and parental effort. Additionally, casual observation suggests that the presence of such examinations may be one of the driving factors behind the large private tutoring industries studied by Dang and Rogers (2008).

\section{CONCLUSion}

Given the fall of Communism and the success of the deregulation movement over the last 40 years, it is widely agreed that free markets have the potential to dramatically improve the quality and lower the cost of many goods and services. At the same time, this period has seen increased dissatisfaction with the public provision of education, leading to calls for more choice and competition in the market for education. This view is illustrated in the introduction to the World Bank's (2004) World Development Report on public service delivery:

"Poor people - as patients in clinics, students in schools, travelers on buses, consumers of water - are the clients of services. They have a relationship with the frontline providers, with schoolteachers, doctors, bus drivers, water companies. Poor people have a similar relationship when they buy something in the market, such as a sandwich (or a samosa, a salteña, a shoo-mai). In a competitive-market transaction, they get the "service" because they can hold the provider accountable. That is, the consumer pays the provider directly; he can observe whether or not he has received the sandwich; and if he is dissatisfied, he has power over the provider with repeat business or, in the case of fraud, with legal or social sanctions. For the services considered heresuch as health, education, water, electricity, and sanitation - there is no direct accountability of the provider to the consumer."

The implication, as the report goes on to discuss, is that introducing greater choice and competition in these services would produce greater accountability and enhance outcomes.

We have discussed a large literature on the effectiveness of this approach, finding that increased competition has had mixed success in raising school test productivity. The key insight we use to explain this finding is that education is not a commodity in the normal sense of the term - in other words education is not like a sandwich or a samosa.

For instance, in many ways education can be better understood as an employment relationship. Students are in some sense "employed" by teachers who must encourage/coach and otherwise cajole their flock into acquiring a set of skills that is beneficial to them in the 
distant future. Most economists would be surprised if a particular industry were required to perform well while not having the right to choose its employees. Yet, we expect (at least public) schools to "employ" all students and to successfully engage them. In a sense, schools are students' first and last opportunity to be treated in this way. Upon graduation, they face a labor market where employers have neither an obligation to employ them, nor to keep them if hired.

Accordingly, we have discussed a model of education that builds upon the employment model of Holmstrom (1999) to capture some of the ways in which education is a complex commodity. These include: i) several of its key outputs are difficult to contract upon; ii) from a consumer's perspective, many of its key products (e.g. long term job market outcomes) are observed significantly after the transaction between student and school has taken place; iii) education requires significant relationship-specific investments that imply that it is costly for students to switch schools; iv) schools' productivity is extremely difficult to disentangle from their student composition (hence the reason for the whole private/public comparison literature), and so reputations can be durably built on student composition; v) unlike policy makers, parents and students do not care about test scores per se - they care about the opportunities that attending a particular school will offer them in the future, and perhaps also about what consumption the school's amenities allow them in the present. ${ }^{35}$

These and other such considerations suggest that "competition plus reputation" is not sufficient to improve school productivity. It is worth highlighting the fact that in a modern market economy, free competition is really a fiction. All markets for sophisticated goods rely upon a complex legal and regulatory framework operating in the background. In the case of transportation, there are safety regulations that must be respected. New drugs must pass regulatory approval before entering the market place. In China, recent experiences with tainted food products are likely to lead to greater food industry regulation.

Since education is also a complex good, the issue is not really one of private versus public provision, but one of market design, and what might be better called "managed competition." Our analysis has highlighted that one key design issue is the link between education and future rewards. In an environment where the labor market cannot easily observe individual productivity, then it will rely upon other signals such as school reputation. This leads to an anti-lemons effect that adversely affects the least able students.

This again reflects that the challenge facing education is similar to an employment relationship, where the firm confronts the problem of motivating its marginal workers. Successful individuals continually receive positive feedback, and hence are encouraged to work hard to

$\overline{35}$ The World Bank (2004) arrives at conclusions distinct from ours precisely because it assumes education is like a conventional good. For example, implicit in its arguments is that parents can easily evaluate a school's wage productivity, when as discussed by Speakman and Welch (2006), this might be close to impossible. 
get more rewards. It is harder to provide rewards to effort for less able individuals. We have argued that the evidence is consistent with the hypothesis that unfettered competition in the market for schools, combined with imperfect information about ability, leads to a stratified school system and an anti-lemons affect - less able individuals are negatively selected when young. These individuals may not expect to receive significantly higher rewards in the future, regardless of how hard they work. Given this prospect, many young people rationally work less hard, perpetuating the cycle of inequality.

To overcome the anti-lemons effect, countries that want to raise their testing performance might choose to make their test scores more meaningful in terms of determining individuals' outcomes. China is an example of such a design, since in its case doing well in national tests has been a route to success for hundreds of years. In short, our point is that if the goal is to improve testing performance to Shangai levels, this might be very hard to achieve merely by introducing private or charter schools. Rather, the structure of the educational system might have to be changed significantly, such that parents and students are able to see clear links between their effort and the outcomes they care about. For example, a system that allows free entry by schools but restricts their ability to select students, combined with high quality individual performance measures, may perform better than a pure laissez-faire system. 


\section{REFERENCES}

Abdulkadiroglu, A., J. Angrist, and P. Pathak (2011). The elite illusion: Achievement effects at boston and new york exam schools. Mimeo, National Bureau of Economic Research Working Paper No. 17264.

Alderman, H., P. Orazem, and E. Paterno (2001). School quality, school cost, and the public/private school choices of low-income households in pakistan. Journal of Human Resources 36(2), 304-326.

Almond, D. and J. M. Currie (2011). Human capital development before five. In O. Ashenfelter and C. D. (Eds.), Handbook of Labor Economics, Volume 4. Elseveir.

Andrabi, T., J. Das, and A. Khwaja (2008). Students today, teachers tomorrow: Identifying constraints on the provision of education. Mimeo, The World Bank.

Angrist, J., E. Bettinger, E. Bloom, M. Kremer, and E. King (2002). The effect of school vouchers on students: Evidence from colombia. American Economic Review 92(5), 15351558.

Angrist, J., E. Bettinger, and M. Kremer (2006, June). Long-term educational consequences of secondary school vouchers: Evidence from administrative records in colombia. American Economic Review 96(3), 847-862.

Angrist, J., D. Lang, and P. Oreopoulos (2009, January). Incentives and services for college achievement: Evidence from a randomized trial. American Economic Journal: Applied Economics 1(1), 136-163.

Angrist, J. D. and K. Lang (2004). Does school integration generate peer effects? evidence from boston's metco program. The American Economic Review 94(5), pp. 1613-1634.

Arnott, R. and J. G. Rowse (1987, APR). Peer group effects and educational-attainment. Journal of Public Economics 32(3), 287-305.

Arrow, K. J. and G. Debreu (1954, July). Existence of an equilibrium for a competitive economy. Econometrica 22(3), 265-290.

Auguste, S. and J. P. Valenzuela (2006). Is it just cream skimming? school vouchers in chile. Mimeo, Fundacion de investigaciones economicas latinoamericanas.

Austen-Smith, D. and R. Fryer (2005, May). An economic analysis of 'acting white'. Quarterly Journal of Economics 120(2), 551-583.

Babcock, P. S. and M. Marks (2010). The falling time cost of college: Evidence from half a century of time use data. Technical report, NBER.

Bandura, A. (1986). Social Foundations of Thought and Action. Englewood Cliffs, New Jersey: Prentice-Hall Inc.

Banerjee, A. (2007). Inside the machine: Toward a new development economics. Boston Review 32(2), 12-18.

Bank, T. W. (2004). Making services work for poor people. Washington, D.C.: The World Bank.

Barrow, L. and C. Rouse (2009). School vouchers and student achievement: Recent evidence and remaining questions. Annual Review of Economics January(17-42).

Bellei, C. (2007). The private-public school controversy: The case of chile. Working paper, Harvard PEPG Working Paper 05-13.

Benabou, R. (1996, Jun). Heterogeneity, stratification, and growth: Macroeconomic implications of community structure and school finance. American Economic Review 86(3), 584-609. 
Bettinger, E., M. Kremer, and J. E. Saavedra (2008). Are educational vouchers only redistributive? Mimeo, Harvard University.

Bishop, J. (2006). Drinking from the fountain of knowledge: Student incentive to study and learn. In E. A. Hanushek and F. Welch (Eds.), Handbook of the Economics of Education, Volume 1, Volume 2, Chapter 15, pp. 909-944. Elsevier B.V.

Bishop, J. H. (1997, May). The effect of national standards and curriculum-based exams on achievement. The American Economic Review 87(2), 260-264.

Bjorklund, A., M. Clark, P.-A. Edin, P. Frederiksson, and A. Krueger (2005). The market comes to education in Sweden. New York: Russell Sage Foundation.

Black, S. (1999, August). Do better schools matter? parental valuation of elementary education. The Quarterly Journal of Economics 114(2), 577-599.

Bravo, D., S. Mukhopadhyay, and P. Todd (2010). Effects of school reform on education and labor market performance: Evidence from chile's universal voucher system. Quantitative Economics 1(2), 47-95.

Card, D. and A. B. Krueger (1992, FEB). Does school quality matter - returns to educationthe characteristics of public-schools in the united-states. Journal of Political Economy $100(1), 1-40$.

Carrell, S. E., B. I. Sacerdote, and J. E. West (2010, July). Beware of economists bearing reduced forms? an experiment in how not to improve student outcomes. NBER Summer Institute 2010.

Chay, K., P. McEwan, and M. Urquiola (2005). The central role of noise in evaluating interventions that use test scores to rank schools. American Economic Review 95(4), $1237-1258$.

Clark, D. (2010). Selective schools and academic achievement. B.E. Journal of Economic Analysis and Policy: Advances.

Clotfelter, C. (1998). Public school segregation in metropolitan areas. Mimeo, National Bureau of Economic Research Working Paper No. 6779.

Coate, S. and G. Loury (1993). Will affirmative-action policies eliminate negative stereotypes? American Economic Review 85 (5), 1220-1240.

Cullen, J., B. Jacob, and S. Levitt (2005). The effect of school choice on student outcomes: An analysis of the chicago public schools. Journal of Public Economics 89(5-6), 729-760.

Cullen, J., B. Jacob, and S. Levitt (2006). The effect of school choice on student outcomes: Evidence from randomized lotteries. Econometrica 74 (5), 1191-1230.

Dale, S. B. and A. B. Krueger (2002, November). Estimating the payoff to attending a more selective college: An application of selection on observables and unobservables. Quarterly Journal of Economics 117(4), 1491-1527.

Dang, H.-A. and H. Rogers (2008). The growing phenomenon of private tutoring: Does it deepen human capital, widen inequalities, or waste resources? The World Bank Research Observer 23(2), 161-200.

Das, J., P. Pandey, and T. Zajonc (2006). Learning levels and gaps in pakistan. Working paper, World Bank Policy Research Working Paper No. 4067.

D'Aspremont, C., J. Gabszewicz, and J. Thisse (1979). Hotellings stability in competition. Econometrica 47(5), 1145-1150.

Debreu, G. (1959). Theory of Value. New Haven, CT: Yale University Press. 
Dixit, A. and J. Stiglitz (1977, June). Monopolistic competition and optimal product diversity. American Economic Review 67, 217-35.

Dobbie, W. and R. Fryer (2011). Exam high schools and academic achievement: Evidence from new york city. Working paper 17286, National Bureau of Economic Research.

Duflo, E., P. Dupas, and M. Kremer (2008, November). Peer effects, teacher incentives, and the impact of tracking: Evidence from a randomized evaluation in kenya. Technical Report 14475, NBER.

Epple, D. and R. E. Romano (1998, March). Competition between private and public schools, vouchers, and peer-group effects. American Economic Review 88(1), 33-62.

Epple, D. and R. E. Romano (2008). Competition between private and public schools, vouchers, and peer-group effects. International Economic Review 49, 1395-1435.

Fack, G. and J. Grenet (forthcoming). When do better schools raise housing prices? evidence from paris public and private schools. Journal of Public Economics.

Friedman, M. (1955). The role of government in education. In R. Solo (Ed.), Economics and the public interest. NJ: Trustees of Rutgers College.

Friedman, M. (1962). Capitalism and Freedom. Chicago: University of Chicago Press. With the assistance of Rose D. Friedman. $23 \mathrm{~cm}$.

Gabszewicz, J. and J. Thisse (1979). Price-competition, quality and income disparities. Journal of Economic Theory 20(3), 340-359.

Gallego, F. (2006). Voucher school competition, incentives, and outcomes: Evidence from chile. Mimeo, MIT.

Hanushek, E. (1995). Interpreting recent research on schooling in developing countries. The World Bank Research Observer August.

Hanushek, E. (1996). The productivity collapse in schools. In W. Fowler (Ed.), Developments in school finance, pp. 183-195. Washington, DC: National Center for Education Statistics.

Hanushek, E. (2010). The economic value of teacher quality. The Economics of Education Review 30(3).

Hart, O. (1975, December). On the optimality of equilibrium when the market structure is incomplete. Journal of Economics Theory 11(3), 418-43.

Hastings, J. and J. Weinstein (2008, November). Information, school choice, and academic achievement: Evidence from two experiments. Quarterly Journal of Economics 123(4), 1373-1414.

Hoekstra, M. (2009, November). The effect of attending the flagship state university on earning: A discontinuity approach. Review of Economics and Statistics 91 (4), 717-724.

Holland, P. W. (1986). Statistics and causal inference. Journal of the American Statistical Association 81(396), 945-960.

Holmstrom, B. (1999, January). Managerial incentive problems: A dynamic perspective. Review of Economic Studies 66(1), 169-182.

Holmström, B. and P. Milgrom (1991). Multi-task principal-agent analyses: Incentive contracts, asset ownership, and job design. Journal of Law, Economics, and Organization 7, $24-52$.

Hotelling, H. (1929, MAR). Stability in competition. Economic Journal 39(153), 41-57.

Hout, M. and S. W. Elliott (Eds.) (2011, June). Incentives and Test-Based Accountability in Education. National Academies Press. 
Hoxby, C. (2000). Does competition among public schools benefit students and taxpayers? American Economic Review 90(5), 1209-1238.

Hoxby, C. (2002). School choice and school productivity (or could school choice be a tide that lifts all boats? Technical Report 8873, National Bureau of Economic Research, Cambridge, MA.

Hoxby, C. M. (2009, Fall). The changing selectivity of american colleges. Journal of Economic Perspectives 23(4), 95-118.

Hsieh, C.-T. and M. Urquiola (2006). The effects of generalized school choice on achievement and stratification: Evidence from chile's school voucher program. Journal of Public Economics 90, 1477-1503.

Jackson, C. K. (2010). Do students benefit from attending better schools?: Evidence from rule based student assignments in trinidad and tobago. The Economic Journal.

Jayachandran, S. (2008). Incentives to teach badly? after school tutoring in developing countries. Mimeo, Stanford University.

Jensen, R. (2010). The perceived returns to education and the demand for schooling. Quarterly Journal of Economics 125(2), 515-548.

Kane, T. J. and D. O. Staiger (2002, Fall). The promise and pitfalls of using imprecise school accountability measures. Journal of Economic Perspectives 16(4), 91-114.

Katz, L., J. Kling, and J. Liebman (2006). Experimental analysis of neighborhood effects. Econometrica 75(1), 83-119.

Kerr, S. (1975, December). On the folly of rewarding A, while hoping for B. Academy of Management Journal 18(4), 769-783.

Kingdon, G. (1996). The quality and efficiency of private and public education: A case study of urban india. Oxford Bulletin of Economics and Statistics 58(1), 57-82.

Kremer, M., E. Miguel, and R. Thornton (2009, August). Incentives to learn. Review of Economics and Statistics $91(3), 437-456$.

Kremer, M. and K. Muralidharan (2006). Public and private schools in rural india. Mimeo, Harvard University.

Krueger, A. and P. Zhu (2004). Another look at the new york city voucher experiment. Behavioral Scientist January, 658-698.

Levin, H. and P. McEwan (2001). Cost effectiveness analysis. Thousand Oaks, California: Sage Publications.

Luce, R. D. and H. Raiffa (1957). Games and Decisions. New York, NY: Dover Publications, Inc.

MacLeod, W. (1985). On the non-existence of equilibria in differentiated product models. Regional Science and Urban Economics 15(2), 245-262.

MacLeod, W. B. (2003, March). Optimal contracting with subjective evaluation. American Economic Review 93(1), 216-240.

MacLeod, W. B. (2007, September). Reputations, relationships and contract enforcement. Journal of Economics Literature XLV, 597-630.

MacLeod, W. B. and D. Parent (1999). Job characteristics and the form of compensation. Research in Labor Economics 18, 177-242.

MacLeod, W. B. and M. Urquiola (2012). Anti-lemons: School reputation and educational quality. Technical Report 6805, IZA. 
Malcomson, J., J. Maw, and B. McCormick (2003, April). General training by firms, apprentice contracts, and public policy. European Economic Review 47(2), 197-227.

Mayer, D., P. Peterson, D. Myers, C. Tuttle, and W. Howell (2002). School choice in new york city after three years: An evaluation of the school choice scholarships program: Final report. Technical report, Mathematica Policy Research, Inc.

Mbiti, I. and A. Lucas (2009). Access, sorting, and achievement: the short-run effects of free primary education in kenya. Technical report, Southern Methodist University.

McEwan, P. (2004). The potential impact of vouchers. Peabody Journal of Education 79(3), 57-80.

McEwan, P. and M. Carnoy (2000). The effectiveness and efficiency of private schools in chile's voucher system. Educational evaluation and policy analysis 22(3), 213-239.

McEwan, P., M. Urquiola, and E. Vegas (2008). School choice, stratification, and information on school performance: Lessons from chile. Economia 8(2), 1-27.

Milkovich, G. T. and A. K. Wigdor (1991). Pay for Performance: Evaluating Performance and Appraisal Merit Pay. Washington, D.C., U.S.A.: National Academy Press.

Mizala, A., P. Romaguera, and M. Urquiola (2007). Socioeconomic status or noise? tradeoffs in the generation of school quality information. Journal of Development Economics 84, $61-75$.

Nash, J. F. (1951). Non-Cooperative games. Annals of Mathematics 54, 286-295.

Neal, D. (2009). Private schools in education markets. In M. Berends, M. Springer, D. Balou, and H. Walberg (Eds.), Handbook of research on school choice. New York, NY: Routledge.

Nechyba, T. J. (2000, MAR). Mobility, targeting, and private-school vouchers. American Economic Review 90(1), 130-146.

Nechyba, T. J. (2006). Income and peer quality sorting in public and private schools. In E. A. Hanushek and F. Welch (Eds.), Handbook of the Economics of Education, Volume 2. Elsevier.

Newhouse, D. and K. Beegle (2006). The effect of school type on academic achievement: Evidence from indonesia. Journal of Human Resources 46(2), 529-557.

Oreopoulos, P. (2003). The long-run consequences of living in a poor neighborhood. Quarterly Journal of Economics 118(4), 1533-1575.

Oster, E. and B. Millett (2010). Do call centers promote enrollment? evidence from india. University of Chicago Discussion Paper.

Patrinos, H., F. Barrera-Osorio, and J. Guaqueta (2009). The role of and impact of publicprivate partnerships in education. Washington, D.C.: The World Bank.

Pop-Eleches, C. and M. Urquiola (2011). The consequences of going to a better school. Mimeo, Columbia University.

Pritchett, L. (2003). Educational quality and costs:a big puzzle and five possible pieces. Mimeo, Harvard University.

Reback, R. (2008). Teaching to the rating: School accountability and the distribution of student achievement. Journal of Public Economics 92, 1394-1415.

Rothstein, J. (2007). Does competition among public schools benefit students and taxpayers? comment. American Economic Review 95(5), 2026-2037.

Saavedra, J. (2009). The learning and early labor market effects of college quality: A regression discontinuity analysis. Mimeo, Harvard University.

Savage, L. J. (1954). The Foundations of Statistics. New York, N.Y.: Wiley. 
Sekhri, S. and Y. Rubinstein (2010). Do public colleges in developing countries provide better education than private ones? evidence from general education sector in india. Mimeo, University of Virginia.

Somers, M.-A., P. McEwan, and D. Willms (2004). How effective are private schools in latin america? Comparative Education Review 48(1), 48-69.

Speakman, R. and F. Welch (2006). Using wages to infer school quality. In E. A. Hanushek and F. Welch (Eds.), Handbook of the Economics of Education, Volume 2. Elsevier.

Spence, M. (1973, August). Job market signaling. The Quarterly Journal of Economics $87(3), 355-374$.

Taylor, F. W. (1911). The principles of scientific management. New York; London: Harper. by Frederick Winslow Taylor ... $23 \mathrm{~cm}$.

Tirole, J. (1988). The Theory of Industrial Organization. Cambridge, MA: MIT Press.

Urquiola, M. (2005). Does school choice lead to sorting? evidence from tiebout variation. American Economic Review 95(4), 1310-1326.

Urquiola, M. and E. Verhoogen (2009). Class-size caps, sorting, and the regression discontinuity design. American Economic Review 99(1).

Williamson, O. E. (1975). Markets and Hierarchies: Analysis and Antitrust Implications. New York: The Free Press.

Woessmann, L. (2007). International evidence on school competition, autonomy, and accountability: A review. Peabody Journal of Education 82(2-3), 473-497.

Columbia University, Department of Economics, 420 West 118th St., MC 3308, New York, NY 10027-7296, USA

E-mail address: bentley.macleod@columbia.edu

Columbia University, Department of Economics, 420 West 118th St., MC 3308, New York, NY 10027-7296, USA 